\title{
Optimization of the Asymmetric Intermediate Reflector Morphology for High Stabilized Efficiency Thin n-i-p Micromorph Solar Cells
}

\author{
Rémi Biron, Simon Hänni, Mathieu Boccard, Céline Pahud, Grégory Bugnon, Laura Ding, Sylvain Nicolay, \\ Gaetano Parascandolo, Fanny Meillaud, Matthieu Despeisse, Franz-Josef Haug, and Christophe Ballif
}

\begin{abstract}
This paper focuses on our latest progress in n-i-p thinmicromorph solar-cell fabrication using textured back reflectors and asymmetric intermediate reflectors, both deposited by lowpressure chemical vapor deposition of zinc oxide. We then present microcrystalline bottom cells with high crystallinity, which yield excellent long wavelength response for relatively thin absorber thickness. In a $1.5-\mu \mathrm{m}$-thick $\mu \mathrm{c}-\mathrm{Si}: \mathrm{H}$ single-junction $\mathrm{n}$-i-p solar cell, we thus obtain a short-circuit current density of $25.9 \mathrm{~mA} \cdot \mathrm{cm}^{-2}$, resulting in an initial cell efficiency of $9.1 \%$. Subsequently, the roughness of the intermediate reflector layer is adapted for the growth of high-performance amorphous silicon (a-Si:H) top cells. Combining bottom cells with high current, an optimal intermediate reflector morphology and a $0.22-\mu \mathrm{m}$-thick a-Si:H top cell, we reach high initial open-circuit voltages of $1.45 \mathrm{~V}$, and we obtain a stabilized cell with an efficiency of $11.1 \%$, which is our best stable efficiency for $n$-i-p solar cells.
\end{abstract}

Index Terms-Intermediate reflector, light trapping, tandem cells, thin-film silicon solar cells.

\section{INTRODUCTION}

C OST-EFFECTIVE high-efficiency thin micromorph solar cells require low-cost substrates and excellent light trapping in both subcells. In the p-i-n configuration, $10.9 \%$ initial efficiency was demonstrated with $2-\mu$ m-thick single-junction $\mu \mathrm{c}-\mathrm{Si}: \mathrm{H}$ cells [1], [2], which were deposited on glass substrates coated with our in-house developed low-pressure chemical vapor deposition zinc oxide (LP-CVD $\mathrm{ZnO}$ ) [3]. In the $\mathrm{n}$-i-p configuration - which permits deposition of cells on flexible and opaque substrates-1.8- $\mu \mathrm{m} \mu \mathrm{c}-\mathrm{Si}: \mathrm{H}$ cells deposited on chemical texture etched $\mathrm{ZnO}: \mathrm{Al}$ on glass substrates with a high-short-circuit current density of $28 \mathrm{~mA} \cdot \mathrm{cm}^{-2}$ were recently fabricated [4]. High $J_{\mathrm{sc}}$ values were also obtained with cells deposited on aluminum foil with quasi-periodic texture [5] or flexible back electrodes of silver deposited at elevated temperature (HotAg) on stainless steel [6]. While HotAg layers exhibit good light trapping, they are deposited at temperatures beyond $200{ }^{\circ} \mathrm{C}$, which are already above the glass transition of

Manuscript received June 5, 2012; revised August 9, 2012 and September 5, 2012; accepted September 8, 2012. This work was funded by the European Union within the FP7 project Silicon-Light under Contract 241277).

The authors are with the Ecole Polytechnique Fédérale de Lausanne (EPFL), Institute of Microengineering (IMT), Photovoltaics and Thin Film Electronics Laboratory, 2000 Neuchâtel, Switzerland (e-mail: remi.biron@epfl.ch).

Color versions of one or more of the figures in this paper are available online at http://ieeexplore.ieee.org.

Digital Object Identifier 10.1109/JPHOTOV.2012.2219502 cost-effective plastics such as polyethylene naphthalate (PEN). This limitation has been recently overcome by nanomimprinting into the plastic substrate and subsequent covering with silver, as reported by Söderström et al. [7]. Although the authors obtained $J_{\mathrm{sc}}$ above $25 \mathrm{~mA} \cdot \mathrm{cm}^{-2}$ on their embossed 2-D grating, the lighttrapping properties of this substrate were relatively moderate since a $\mu \mathrm{c}-\mathrm{Si}: \mathrm{H}$ absorber layer thickness of up to about $2.5 \mu \mathrm{m}$ was required. Moreover, such thick $\mu \mathrm{c}-\mathrm{Si}: \mathrm{H}$ absorber layers are not optimal for efficient charge collection on textured substrate, leading to the degradation of both open-circuit voltage $V_{\text {oc }}$ and fill factor (FF) [7], [8]. Recently, Escarré et al. demonstrated ultraviolet imprinting of LP-CVD ZnO back electrodes [9] with high fidelity, opening a route to flexible low-cost substrates with improved light trapping. In n-i-p micromorph devices, an intermediate reflector layer (IRL) consisting of $n$-doped silicon oxide and replacing the n-layer in the tunnel junction has been successfully introduced since it reduces parasitic absorption in the junction. It thus leads to a significant gain in the top cell current without losing in total current [10]. Nevertheless in our case, the n-doped silicon oxide IRL inserted between the p-layer of the bottom cell and the n-layer of the top cell leads to a reduction of the total current in our micromorph devices. The latter are often limited by the top cell current since the quasi-flat amorphous silicon (a-Si:H)/IRL interface only reflects light but does not adequately scatter it. Better light scattering was achieved with the introduction of an IRL made from LP-CVD ZnO reported by Söderström et al. [11]. Since the growth of the $\mathrm{ZnO}$ introduces a suitable light-trapping texture for the top cell, regardless of the underlying morphology of the bottom cell, this concept is called an asymmetric intermediate reflector (AIR). However, the higher conductivity of this AIR compared with IRLs based on silicon oxide was reported to decrease the FF and $V_{\text {oc }}$ since it permits current leakage through the eventual shunts in the device [12]. Electrical properties of $\mathrm{p}-\mathrm{i}-\mathrm{n}$ micromorph cells with LP-CVD ZnO IRLs were improved by Bugnon et al. by increasing the in-plane resistivity of the IRL, which partially quenches current leakage paths [12].

In this contribution, we demonstrate thin $\mu \mathrm{c}-\mathrm{Si}: \mathrm{H}$ singlejunction cells with high crystallinity which exhibit high $J_{\mathrm{sc}}$ values and are compatible with bottom cell application in micromorph devices. Then, we determine an appropriate AIR roughness for the growth of high-performance a-Si:H top cells, and we discuss the influence of the AIR on our micromorph cells. Finally, we combine these developments into micromorph devices with initial efficiencies up to $12.4 \%$. 


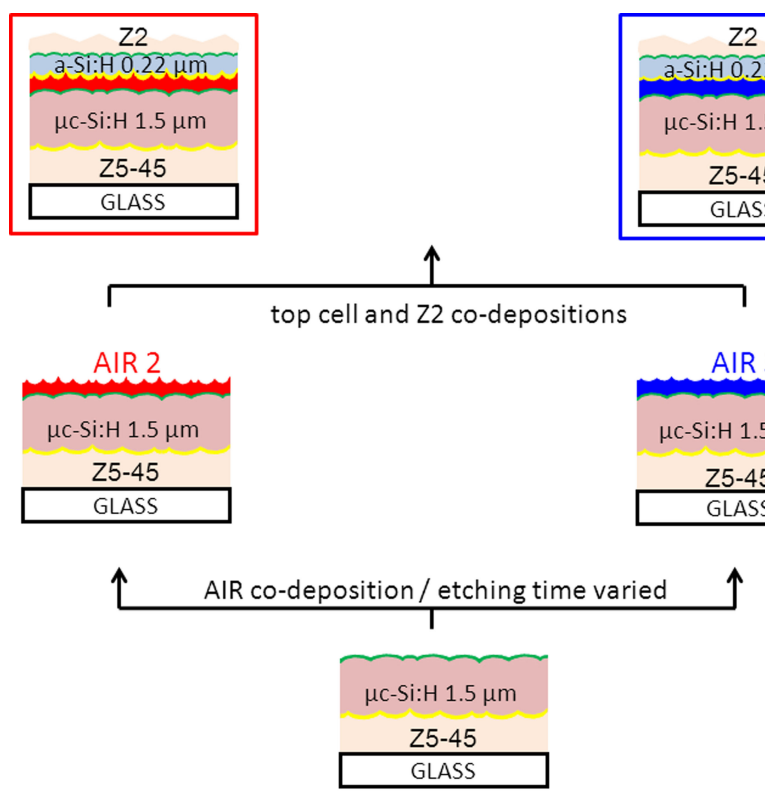

25-45 and bottom cell co-depositions on glass

Fig. 1. Sketch of the different steps of the micromorph cell fabrication.

\section{EXPERIMENTAL DETAILS}

Fig. 1 shows the micromorph device fabrication steps. We used LP-CVD for the deposition of 5- $\mu$ m-thick $\mathrm{ZnO}$ films on glass. The surface of the $\mathrm{ZnO}$ films is subjected to a plasma treatment of $45 \mathrm{~min}$ (Z5-45 substrate). Then, we deposited microcrystalline cells with high crystallinity $\left(R_{c}>67 \%\right)$ in n-i-p sequence. Subsequently, $\mathrm{ZnO}$ electrodes were grown by LPCVD. For single junction cells, we used 2- $\mu$ m-thick films (Z2) as front contact. For tandem cells, we used 1.1- $\mu$ m-thick films as AIR. The AIRs of two identical samples were then subjected to a standard plasma treatment of 30 and $60 \mathrm{~min}$ (AIR 2 and 3, respectively), which has been demonstrated to change the $V$-shape morphology of the AIR into an $U$-shape morphology [13]. After the treatment, the tandem cells were completed in a co-deposition with $0.22-\mu$ m-thick amorphous top cells and Z2 front contacts. Single-junction amorphous cells were tested on two different back electrodes deposited on glass. The first type consists of sputtered silver deposited at an elevated temperature around $150^{\circ} \mathrm{C}$, subsequently covered by $60 \mathrm{~nm}$ of sputtered $\mathrm{ZnO}$ (denoted by Ag150). The second type consists of $2-\mu \mathrm{m}$-thick LP-CVD ZnO, plasma treated for 0,4 , and $10 \mathrm{~min}$ (denoted by Z2-0, Z2-4 and Z2-10, respectively), which changes the surface morphology with the same mechanism than the plasma treatment used for AIRs. For clarity, the parameters and uses of the different LP-CVD ZnO layers are presented in Table I.

Finally, on each substrate, 16 cells of $0.25 \mathrm{~cm}^{2}$ were patterned by liftoff lithography and plasma dry etching. For the cell characterization, we measured current-voltage $(I-V)$ characteristics under a simulated AM1.5 g spectrum (WACOM WXS-220 SL2, AM1.5GMM), and we determined the external quantum efficiency (EQE). The $V_{\mathrm{oc}}$ and the FF were calculated from the $I-V$ measurement, while $J_{\mathrm{sc}}$ was calculated from the $\mathrm{EQE}$. The
TABLE I

LP-CVD ZNO LAYERS PARAMETERS

\begin{tabular}{lcccc}
\hline \hline \multicolumn{1}{c}{ Name } & $\begin{array}{c}\text { Thickness } \\
(\mu \mathrm{m})\end{array}$ & $\begin{array}{c}\text { Treatment } \\
\text { time }(\mathrm{min})\end{array}$ & $\begin{array}{c}\text { roughness } \\
(\mathrm{nm})\end{array}$ & cell \\
\hline Back contact & & & & \\
Z5-45 & 4.9 & 45 & 116 & $\mu \mathrm{c}-\mathrm{Si}: \mathrm{H}$ \\
Z2-0 & 1.9 & 0 & 77 & $\mathrm{a}-\mathrm{Si}: \mathrm{H}$ \\
Z2-4 & 1.9 & 4 & - & $\mathrm{a}-\mathrm{Si}: \mathrm{H}$ \\
Z2-10 & 1.9 & 10 & 57 & a-Si:H \\
AIR & & & & \\
AIR1 & 1.1 & 15 & 59 & a-Si:H \\
AIR2 & 1.1 & 30 & 49 & a-Si:H \\
AIR3 & 1.1 & 60 & 35 & a-Si:H \\
Front contact & & & & \\
Z2 & 2.0 & 0 & 77 & - \\
\hline \hline
\end{tabular}

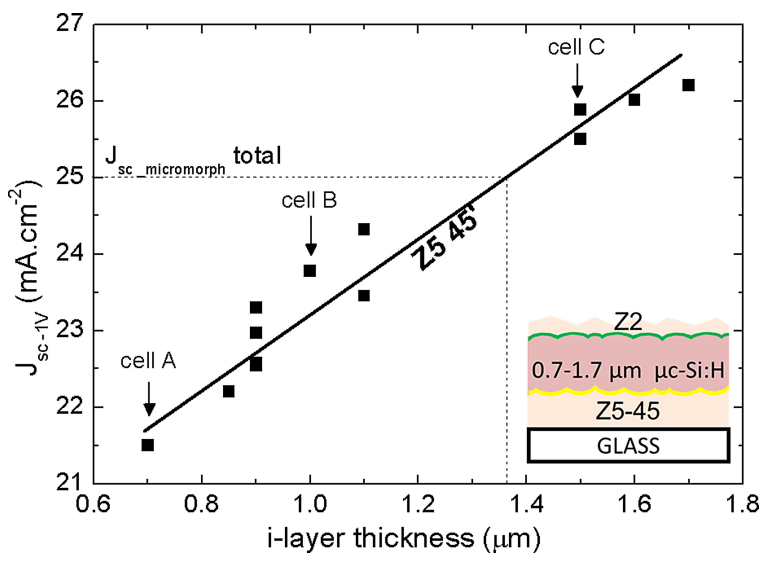

Fig. 2. Effect of i-layer thickness on $J_{\mathrm{sc}-1 \mathrm{~V}}$. The variation of $J_{\mathrm{sc}-1 \mathrm{~V}}$ for the same i-layer thickness are explained by either various p-layer thickness or charge collection issue.

stabilized efficiencies are measured after degradation of $1000 \mathrm{~h}$ at $50{ }^{\circ} \mathrm{C}$ under $\mathrm{AM} 1.5 \mathrm{~g}$ illumination.

The Raman crystallinity $R_{c}$ was measured from the p-side of the cells using an $\mathrm{Ar}+$ laser with 514-nm excitation wavelength. For the optical analysis of the AIR layer, reference films of $1.1-\mu \mathrm{m}$ thickness were deposited on glass substrate. Plasma treatments for 15, 30, and 60 min are denoted by AIR1, AIR2, and AIR3, respectively. The surface roughness of the substrates and the AIRs was determined by AFM measurements.

\section{RESUlTS AND DISCUSSION}

\section{A. Bottom Cell I-Layer Thickness Series with High $R_{c}$ for High-Current Matching in Micromorph Devices}

Our design goal for high-efficiency tandem cells with IR is to reach a minimal matched current density of $12.5 \mathrm{~mA} \cdot \mathrm{cm}^{-2}$, as proposed by Guha et al. [14]. The bottom cells are therefore required to deliver at least twice this value, i.e., $25 \mathrm{~mA} \cdot \mathrm{cm}^{-2}$. In this subsection, we discuss the dependence of the current density on i-layer thickness in $\mu \mathrm{c}-\mathrm{Si}$ :H cells. We use Z5-45 substrates since they combine high light trapping with satisfactory $V_{\mathrm{oc}}$ and FF values. Moreover, we concentrate on i-layers with high $R_{c}$ because we prefer the bottom cell to be thin but, nevertheless, to absorb a sufficient amount of IR light. Fig. 2 shows the influence of the i-layer thickness on the photocurrent of 
TABLE II

Best Single-Junction $\mu$ C-Si:H Cells PaRAmeters

\begin{tabular}{lllllll}
\hline \hline Cell & $\begin{array}{l}\mathrm{p} \text { - side } \\
\mathrm{R}_{\mathrm{c}}\end{array}$ & $\mathrm{V}_{\mathrm{oc}}(\mathrm{V})$ & $\mathrm{FF}$ & $\mathrm{J}_{\mathrm{sc}}$ & $\mathrm{J}_{\mathrm{sc} 600-1100}$ & $\eta(\%)$ \\
\hline $\mathrm{A}$ & 0.71 & 0.54 & 0.69 & 21.6 & 12.3 & 8.05 \\
$\mathrm{~B}$ & 0.72 & 0.52 & 0.67 & 23.8 & 13.9 & 8.19 \\
$\mathrm{C}$ & 0.68 & 0.52 & 0.68 & 25.9 & 16.1 & 9.14 \\
\hline \hline
\end{tabular}

single-junction $\mu \mathrm{c}$-Si:H n-i-p solar cells. In order to illustrate the light-trapping potential, the points on the graph represent the $J_{\mathrm{sc}}$ value measured at $-1 \mathrm{~V}$ applied bias $J_{\mathrm{sc}-1 \mathrm{~V}}$, using the best cell of each experiment. In the studied range of i-layer thicknesses, we observe a linear increase of $J_{\mathrm{sc}-1 \mathrm{~V}}$ from 21.7 to $26.2 \mathrm{~mA} \cdot \mathrm{cm}^{-2}$ (solid line).

The parameters $V_{\mathrm{oc}}, J_{\mathrm{sc}}, \mathrm{FF}$, and efficiency of three representative cells A, B, and C are listed in Table II. The i-layer thickness of these cells are $0.7,1.0$, and $1.5 \mu \mathrm{m}$, respectively, and the highest initial efficiency of this series of microcrystalline single-junction cells is obtained for cell C, which reaches $9.14 \%$. We note that thicknesses of approximately $1.4 \mu \mathrm{m}$ are required to reach the design goal of $25 \mathrm{~mA} \cdot \mathrm{cm}^{-2}$ (dashed lines in Fig. 2). In order to evaluate the suitability of such single-junction cells for tandem cells, Table II includes the quantity $J_{\text {sc }-600-1100}$, which represents the current density in the 600-1100-nm range. $J_{\text {sc }}$ values are in $\mathrm{mA} \cdot \mathrm{cm}^{-2}$.

The gain in $J_{\mathrm{sc}}$ by increasing the thickness of the absorber layer occurs mainly between 600 and $1100 \mathrm{~nm}$. The rest of the gain for cell C compared with cell $\mathrm{A}$ is explained by the better response in the blue part of the spectrum, suggesting that the p-layer is thicker for the cell A.

Despite the high crystallinity, we obtain satisfactory $V_{\text {oc }}$ and FF values which we attribute to the use of doped layers of silicon oxide, which were reported to quench current leakage through the device [15], [16], as well as hydrogen dilution profiling, which was reported to improve cell performances [17].

\section{B. Influence of the Substrate Roughness on the a-Si:H Top-Cell Performance}

In order to assess the performance of the amorphous top cells, we deposited 220-nm-thick a-Si:H cells on substrates with different roughnesses $\sigma_{\text {rms }}$. Fig. 3 shows the $V_{\text {oc }}$ and FF of the five best cells deposited on Ag150 and Z2-like substrates. We note that the $V_{\text {oc }}$ remains above $0.93 \mathrm{~V}$ for relatively lowsubstrate roughness, i.e., Ag150 and Z2-10 substrates. However, the $V_{\text {oc }}$ decreases drastically to $0.88 \mathrm{~V}$ when cells are deposited on $\mathrm{Z} 2-4$, and continues to drop below $0.79 \mathrm{~V}$ for the roughest Z2-0 substrates. The FF decreases linearly with the roughness with values as low as 0.60 for Z2-0, where the $I-V$ curve of this cell indicates the presence of shunt paths through the device.

In this experiment, the gain in $J_{\mathrm{sc}}$ (not shown here) with the substrate roughness does not compensate the decrease of both FF and $V_{\text {oc }}$, leading to lower efficiencies. The high $V_{\text {oc }}$ values above $0.93 \mathrm{~V}$ obtained on $\mathrm{Ag} 150$ and Z2-10 substrates are ascribed to the use of a silicon oxide p-layer that was reported to improve the $\mathrm{i} / \mathrm{p}$ interface, enhancing the $V_{\text {oc }}$ [18]. These results show that the a-Si:H cell performance is very sensitive to the

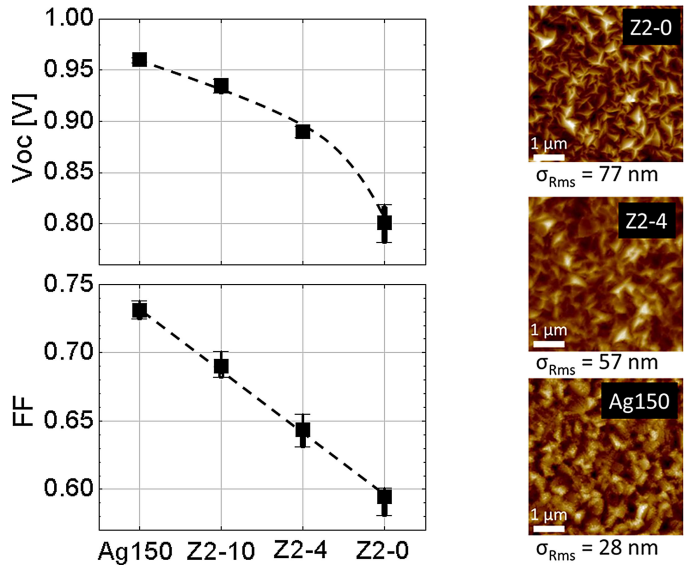

Fig. 3. Average $V_{\mathrm{oc}}$ and FF of the five best a-Si:H cells in the initial state on the four tested substrate (right). AFM images of the Ag150, Z2-4 and untreated $\mathrm{Z} 2$ substrates. Image size: $5 \times 5 \mu \mathrm{m}$ (left).

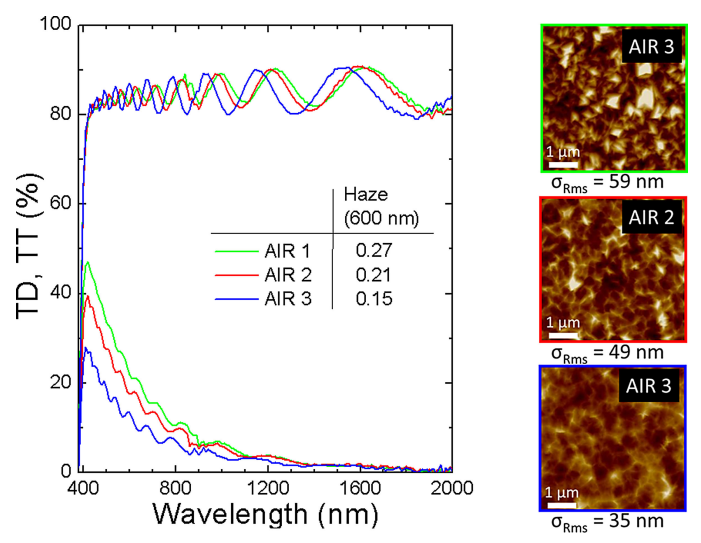

Fig. 4. Total and diffused transmission (TT and TD, respectively) of the AIR layers as a function of the wavelength for plasma-treatment times. The haze is calculated as the ratio of TD over TT (left). The optical system of our haze measurement is light beam/air/ZnO/glass/air/integration sphere. The AFM images and corresponding roughness of the three AIR layers (right).

substrate roughness. For plasma-etched U-shaped LP-CVD ZnO substrates, we conclude that their roughness should be below $57 \mathrm{~nm}$ because this roughness value is already detrimental for the electrical performances of the a-Si:H cells.

\section{Optimization of the AIR Roughness}

We studied optical and morphological properties of the AIR reference layers deposited on glass substrate. The AFM images in Fig. 4 illustrate the change of the surface morphology from $V$ to $\mathrm{U}$ shape with the plasma-treatment duration. The surface roughness is reduced from 60 (AIR 1) to $35 \mathrm{~nm}$ (AIR3). At the same time, the haze in transmission is reduced from 0.27 to 0.15 (evaluated at $600 \mathrm{~nm}$ ).

Based on the results discussed in the previous section, roughness data indicate that the AIR 1 morphology appears to be too rough for the growth of a-Si:H top cells, while both AIRs 2 and 3 are promising candidates for the integration into micromorph devices. 


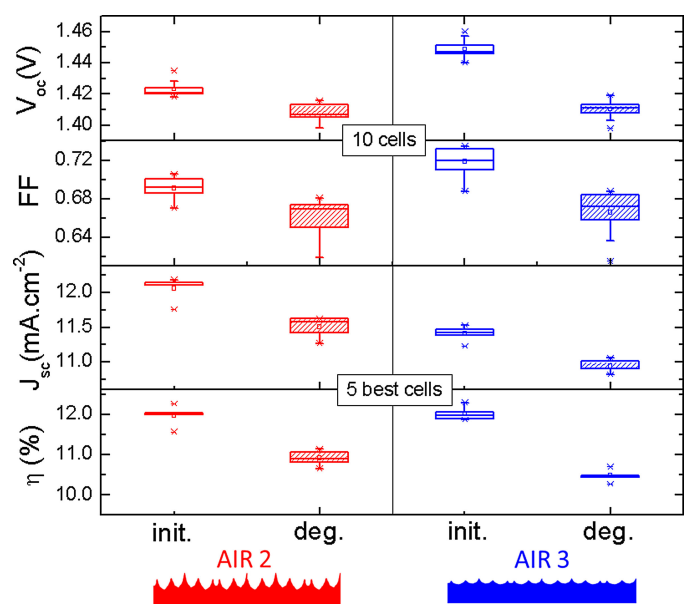

Fig. 5. Initial (empty boxes) and stable (patterned boxes) $V_{\mathrm{oc}}, \mathrm{FF}, J_{\mathrm{sc}}$, and efficiencies of micrormorph cells codeposited on Z5-45 substrates. Both devices are top-cell limited, and thus, $J_{\mathrm{sc}}$ values displayed in this figure are those of the top cells.

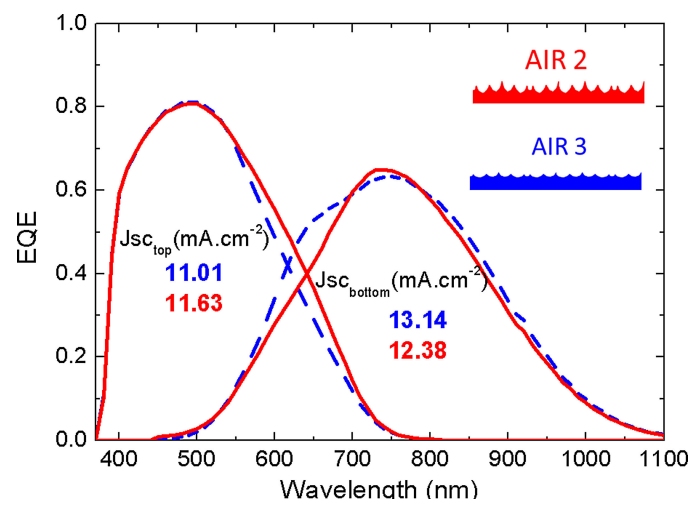

Fig. 6. EQE of the best stabilized micromorph cells with AIR 2 (red) and 3 (blue) deposited on Z5-45 substrates with stable efficiencies of 11.1 and $10.7 \%$, respectively.

\section{Introduction of AIRs 2 and 3 in Micromorph Devices With High Stabilized Efficiencies}

In this section, we discuss two types of micromorph devices incorporating Z5-45 back reflectors, 1.5 - $\mu$ m-thick bottom cells (type $\mathrm{C}$ shown in Table II), AIR layers of types 2 and 3, $0.22-\mu \mathrm{m}$-thick amorphous top cells, and, finally, Z2 front contacts. As illustrated in Fig. 1, all steps except the AIR are carried out by codeposition.

Fig. 5 shows the electrical parameters of micromorph devices with AIRs 2 (left panel) and 3 (right panel). The box charts denote averages over 10 cells for the $V_{\mathrm{oc}}$ and FF and averages of the five best cells for $J_{\mathrm{sc}}$ and the efficiency.

Fig. 5 shows that the efficiencies of the two devices are similar in the initial state. Both devices are top cell limited, but a larger limiting current is observed on AIR 2 due to its increased roughness, which yields a higher top cell current. At the same time, AIR 2 yields lower $V_{\text {oc }}$ and FF compared with AIR 3.

In the degraded state, median $V_{\mathrm{oc}}$ and $\mathrm{FF}$ of the two cell types become comparable. The degradation of the top-cell $J_{\mathrm{sc}}$ is similar, leading to higher stabilized efficiencies for AIR 2 due to its larger starting value. Fig. 6 illustrates that the gain
TABLE III

Best Micromorph CELls PARAMETERS

\begin{tabular}{llllllll}
\hline \hline $\begin{array}{l}\text { Cells } \\
\text { with }\end{array}$ & State & $\begin{array}{l}\mathrm{V}_{\text {oc }} \\
(\mathrm{V})\end{array}$ & FF & $\mathrm{J}_{\text {sc-top }}{ }^{*}$ & $\mathrm{~J}_{\text {sc-bottom }}{ }^{*}$ & $\begin{array}{l}\eta \\
(\%)\end{array}$ & $\begin{array}{l}\text { Deg. } \\
(\%)\end{array}$ \\
\hline AIR 2 & Init & 1.43 & 0.71 & 12.2 & 12.4 & 12.4 & \\
& Deg. & 1.41 & 0.68 & 11.6 & 12.4 & 11.1 & 10 \\
AIR 3 & Init & 1.45 & 0.74 & 11.5 & 13.1 & 12.3 & \\
& Deg. & 1.41 & 0.69 & 11.0 & 13.1 & 10.7 & 13 \\
\hline \hline
\end{tabular}

$* \mathrm{~J}_{\mathrm{sc}}$ values are given in $\mathrm{mA.cm}$

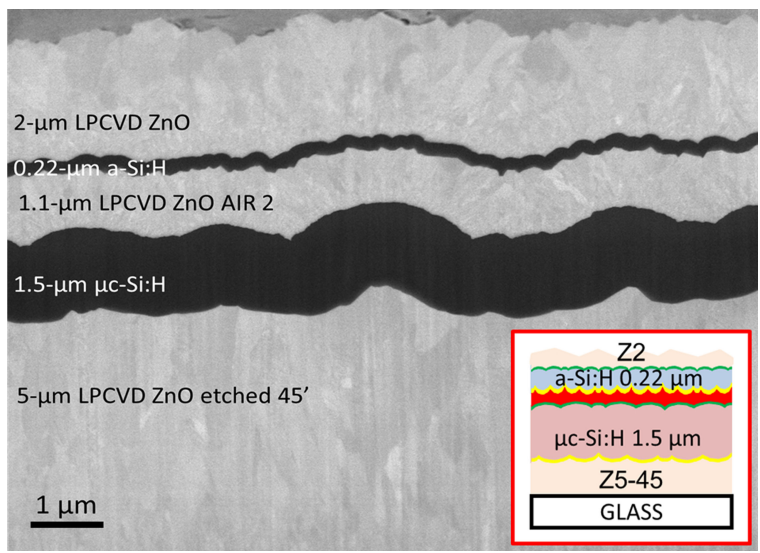

Fig. 7. SEM micrograph of the cross section of a micromorph cell deposited on Z5-45 substrates. Silicon layer appear in dark while LP-CVD layers are brighter with different gray levels for the grains. Red circles indicate potential pinch areas, which appear at the bottom-cell surface.

with AIR 2 occurs mainly from 550 to $700 \mathrm{~nm}$. The electrical parameters of the best cells are summarized in Table III; our best stabilized cell achieves an efficiency of $11.1 \%$ after a relative degradation of only $10 \%$.

We consider the values of the best micromorph devices shown in Table III as references for the discussion on the performances of the devices in both initial and degraded states. The higher initial FF value of the device with AIR 3 can be explained by the higher current mismatching of $1.6 \mathrm{~mA} \cdot \mathrm{cm}^{-2}$ between subcells compared with the cell with AIR 2. We can ascribe the difference in initial $V_{\text {oc }}$ of $20 \mathrm{mV}$ to the AIR roughness which decreases the $V_{\text {oc }}$ of the a-Si:H top cell as demonstrated in subsection A. The lower degradation of the FF in the device with AIR 2 can be attributed to the fact that the cell is mismatched in the stabilized state, whereas it is not the case in the initial state, as indicated by the $J_{\mathrm{sc}}$ values.

A SEM cross section of our currently the best stabilized n-i-p micromorph solar cell with AIR 2 is presented in Fig. 7. The excellent $V_{\text {oc }}$ values of both devices before and after degradation can be explained to some extent by the stacking of the layers. Indeed, the AIR layer that grows perpendicularly to the bottomcell surface inhibits pinched areas (see the red circles in Fig. 7), where structural defects ("cracks") are likely to form, reducing the $V_{\text {oc }}$ of the cell that grows above. Thus, we conclude that the a Si:H top cell deposited after the AIR is less affected by the cracks, leading to higher $V_{\text {oc }}$ values. 


\section{CONCLUSION}

We demonstrated stabilized efficiencies of $11.1 \%$ using less than $2 \mu \mathrm{m}$ of silicon via the fabrication of micromorph cells with a LP-CVD ZnO AIR. High $V_{\text {oc }}$ values of $1.45 \mathrm{~V}$ are achieved by developing silicon oxide doped layer for both subcells and optimizing the plasma-etched AIR morphology, which provides the desired texture for high performance top cells. The high $R_{c}$ $\mu \mathrm{c}-\mathrm{Si}$ :H cells developed in this contribution offer high $J_{\mathrm{sc}}$ values in the bottom cell while keeping relatively thin micromorph devices. The stabilized efficiency of these devices could be further increased by thickening moderately the top cell regarding its degradation since our micromorph devices are top-limited at this stage. Furthermore, FF values can be improved by introducing innovative substrates, which favor a better growth of the bottom cell while maintaining efficient light trapping.

\section{ACKNOWLEDGMENT}

The authors would like to thank M. Duchamp from the Forschungszentrum Jülich for the FIB cross sections, M. Leboeuf from the Centre Suisse d'Electronique et de Microtechnique SA, Neuchâtel, Switzerland, for AFM measurements, and M. Benkhaira from the PVLAB for LP-CVD ZnO depositions.

\section{REFERENCES}

[1] G. Bugnon, G. Parascandolo, T. Söderström, P. Cuony, M. Despeisse, S. Hänni, J. Holovský, F. Meillaud, and C. Ballif, "A new view of microcrystalline silicon: The role of plasma processing in achieving a dense and stable absorber material for photovoltaic applications," Adv. Funct. Mater., vol. 22, no. 17, pp. 3665-3671, 2012.

[2] S. Hänni, D. T. L. Alexander, L. Ding, G. Bugnon, M. Boccard, C. Battaglia, P. Cuony, J.Escarré, G. Parascandolo, S. Nicolay, M. Cantoni, M. Despeisse, F. Meillaud, and C. Ballif, "On the interplay between material quality and interfaces in high-efficiency microcrystalline silicon solar cells," IEEE J. Photovoltaic, 2012, to be published.

[3] S. Faÿ, J. Steinhauser, N. Oliveira, E. Vallat-Sauvain, and C. Ballif, "Optoelectronic properties of rough LP-CVD ZnO:B for use as TCO in thin-film silicon solar cells," Thin Solid Films, vol. 515, pp. 8558-8561, 2007.

[4] Chen, Y. Huang, A. Dasgupta, M. Luysberg, L. Houben, D. Yang, R. Carius, and F. Finger, "Microcrystalline silicon carbide window layers in thin film silicon solar cells," Solar Mater., vol. 98, pp. 370-378, 2012.

[5] H. Sai, H. Fujiwara, M. Kondo, and Y. Kanamori, "Enhancement of light trapping in thin film hydrogenated microcrystalline Si solar cells using back reflector with self-ordered dimple pattern," Appl. Phys. Lett., vol. 93, 143501, 2008.

[6] J. Yang, B. Yana, G. Yue, and S. Guha, "Light trapping in hydrogenated amorphous and nano-crystalline silicon thin film solar cells," Mater. Res. Soc. Symp. Proc., vol. 1153, 1153 A13-02, 2009.

[7] T. Söderström, F.-J. Haug, V. Terrazzoni-Daudrix, and C. Ballif, "LPCVD Flexible micromorph tandem a Si $/ \mu \mathrm{c}$-Si solar cell," J.Appl.Phys., vol. 107, 014507, 2010.

[8] M. Boccard, P. Cuony, M. Despeisse, D. Dominé, A. Feltrin, N. Wyrsch, and C. Ballif, "Substrate dependent stability and interplay between optical and electrical properties in $\mu \mathrm{c}-\mathrm{Si}: H$ single junction solar cells," Sol. Energy Mater. Sol. Cells, vol. 95, pp. 195-198, 2011.

[9] J. Escarre, K. Söderström, C. Battaglia, F.-J. Haug, and C. Ballif, "High fidelity transfer of nanometric random textures by UV embossing for thin film solar cells applications," Sol. Energy Mater. Sol. Cells, vol. 95, pp. 881-886, 2011.

[10] B. Yan, G. Yue, L. Sivec, J. Yang, S. Guha, and C-S. Jinag, "Innovative dual function nc-SiOx:H layer leading to a $>16 \%$ efficient multi-junction thin-film silicon solar cell," Appl. Phys. Lett., vol. 99, 113512, 2011.

[11] T. Söderström, D. Dominé, A. Feltrin, M. Despeisse, F. Meillaud, G. Bugnon, M. Boccard, P. Cuony, F.-J. Haug, S. Fay, S. Nicolay, and C. Ballif, "ZnO Transparent conductive oxide for thin film silicon solar cells," Proc. SPIE, vol. 7603-09, pp. 3-12, 2010.
[12] G. Bugnon, T. Söderström, S. Nicolay, L. Ding, M. Despeisse, A. Hedler J. Eberhardt, C. Wachtendorf, and C. Ballif, "LPCVD ZnO-based intermediate reflector for micromorph tandem solar cells," Solar Energy Mater. Solar Cells, vol. 95, pp. 2161-2166, 2010.

[13] J. Bailat, D. Dominé, R. Schlüchter, J. Steinhauser, S. Faÿ, F. Freitas, C. Bücher, L. Feitknecht, X. Niquille, T. Tscharner, A. Shah, and C. Ballif, "High-efficiency p-i-n microcrystalline and micromorph solar cells deposited on LPCVD ZnO coated glass substrates," in Proc. 4th World Conf. Photovoltaic Energy Convers., May 8-12, 2006, pp. 1533-1536.

[14] S. Guha, J. Yang, and B. Yan, "6.08 - Amorphous and nanocrystalline silicon solar cells and modules," Comprehensive Semicond. Sci. Technol., vol. 6, pp. 308-352, 2011.

[15] M. Despeisse, G. Bugnon, A. Feltrin, M. Stueckelberger, P. Cuony, F. Meillaud, A. Billet, and C. Ballif, "Resistive interlayer for improved performance of thin film silicon solar cells on highly textured substrate," Appl. Phys. Lett., vol. 96, 073507, 2010.

[16] P. Cuony, M. Marending, D. T. L. Alexander, M. Boccard, G. Bugnon, M. Despeisse, and C. Ballif, "Mixed-phase p-type silicon oxide containing silicon nanocrystals and its role in thin-film silicon solar cells," Appl. Phys. Lett., vol. 97, 213502, 2010.

[17] Yan, G. Yue, J. Yang, and S. Guha, "Hydrogen dilution profiling for hydrogenated microcrystalline," Appl. Phys. Lett., vol. 85, pp. 1955-1957, 2004.

[18] R. Biron, C. Pahud, F.-J. Haug, J. Escarré, K. Söderström, and C. Ballif, "Window layer with $\mathrm{p}$ doped silicon oxide for high $\mathrm{V}_{\mathrm{oc}}$ thin-film silicon n-i-p solar cells," J. Appl. Phys., vol. 110, 124511, 2011.

Rémi Biron was born in Toulouse, France, on January 26, 1986. He received the M.Sc. degree in material science from the Institut National des Sciences Appliquées, Toulouse, France, in 2009. He is currently working toward the Ph.D. degree in material science with the Ecole Polytechnique Fédérale de Lausanne, EPFL with the Laboratory of Photovoltaics and Thin-Film Electronics, Institute of Microengineering, Neuchâtel, Switzerland.

His main research interests include physics and engineering of interfaces in high-efficiency thin-film silicon n-i-p tandem solar cells.

Simon Hänni, photograph and biography not available at the time of publication.

Mathieu Boccard, photograph and biography not available at the time of publication.

Céline Pahud, photograph and biography not available at the time of publication.

Grégory Bugnon, photograph and biography not available at the time of publication.

Laura Ding, photograph and biography not available at the time of publication.

Sylvain Nicolay, photograph and biography not available at the time of publication.

Gaetano Parascandolo, photograph and biography not available at the time of publication.

Fanny Meillaud, photograph and biography not available at the time of publication.

Matthieu Despeisse, photograph and biography not available at the time of publication.

Franz-Josef Haug, photograph and biography not available at the time of publication.

Christophe Ballif, photograph and biography not available at the time of publication. 